\title{
ANALISIS PENERAPAN AKUNTANSI LINGKUNGAN PADA BADAN RUMAH SAKIT UMUM DAERAH (BRSUD) TABANAN
}

\author{
Ni Made Indrawati I G A Intan Saputra Rini* \\ Fakultas Ekonomi Universitas Warmadwewa, Denpasar, Bali \\ *E-Mail: intansaputrarini@gmail.com
}

\begin{abstract}
This research entitled "Analysis of Application of Environmental Accounting at Badan Umum Umum Daerah (BRSUD) Tabanan". This study aims to determine the application of environmental accounting at the Regional General Hospital Board (BRSUD) Tabanan as an effort to reduce the environmental impact caused by hospital operational activities and to know the reporting of environmental costs in the financial statements of the hospital. This research is qualitative descriptive research. The variables used in this research are environmental activity and environmental cost treatment. The result of this research is environmental activity done by Badan Badan Umum Umum Daerah (BRSUD) Tabanan that is solid and liquid waste processing by using incinerator and WWTP. Badan General Hospital District (BRSUD) Tabanan not yet apply environmental accounting perfectly according to existing theory. The Tabanan Regional Hospital Board (BRSUD) identifies the environmental costs as direct expenditure and indirect expenditure, recognizes the environmental costs when it has benefited from it even though cash has not yet been issued, the measurement of environmental costs with rupiah monetary units referring to the realization of the previous period costs by the amount of costs incurred, presenting and disclosing the overall environmental costs in the financial statements together with similar costs such as service fees and general and administrative costs. The cost of environmental quality issued by the Regional General Hospital Board (BRSUD) Tabanan amounted to $28.21 \%$ of operational cost and budget management has reached $76.62 \%$.
\end{abstract}

\section{Keywords: Environmental accounting, environmental activities, and environmental costs}

\begin{abstract}
Abstrak
Penelitian ini berjudul "Analisis Penerapan Akuntansi Lingkungan pada Badan Rumah Sakit Umum Daerah (BRSUD) Tabanan”. Penelitian ini bertujuan untuk mengetahui penerapan akuntansi lingkungan pada Badan Rumah Sakit Umum Daerah (BRSUD) Tabanan sebagai upaya untuk mengurangi dampak lingkungan yang ditimbulkan akibat kegiatan operasional rumah sakit dan mengetahui pelaporan biaya lingkungan pada laporan keuangan rumah sakit. Penelitian ini adalah penelitian deskriptif kualitatif. Variabel yang digunakan dalam penelitian ini adalah aktivitas lingkungan dan perlakuan biaya lingkungan. Hasil dari penelitian ini adalah aktivitas lingkungan yang dilakukan Badan Rumah Sakit Umum Daerah (BRSUD) Tabanan yaitu pengolahan limbah padat dan cair dengan menggunakan incinerator dan IPAL. Badan Rumah Sakit Umum Daerah (BRSUD) Tabanan belum menerapakan akuntansi lingkungan secara sempurna sesuai teori yang ada. Badan Rumah Sakit Umum Daerah (BRSUD) Tabanan mengidentifikasi biaya lingkungan sebagai belanja langsung dan belanja tidak langsung, mengakui biaya lingkungan pada saat sudah mendapat manfaat dari hal tersebut meskipun kas belum dikeluarkan, pengukuran biaya lingkungan dengan satuan moneter rupiah yang mengacu pada realisasi biaya periode sebelumnya sebesar kos yang dikeluarkan, menyajikan dan mengungkapkan biaya lingkungan secara keseluruhan dalam laporan keuangan bersama-sama dengan biayabiaya yang sejenis seperti biaya layanan dan biaya administrasi dan umum. Biaya kualitas lingkungan yang dikeluarkan Badan Rumah Sakit Umum Daerah (BRSUD) Tabanan sebesar 28,21\% dari biaya operasional dan pengelolaan anggaran sudah mencapai $76,62 \%$.
\end{abstract}

Kata kunci: Akuntansi lingkungan, aktivitas lingkungan, dan biaya Lingkungan

\section{PENDAHULUAN}

\section{A. Latar Belakang}

Pada era globalisasi saat ini isu tentang kerusakan alam dan pemanasan global menjadi perhatian yang serius. Bumi yang sudah tidak sehat lagi menunjukkan berbagai macam gejala, seperti kondisi cuaca yang tidak normal dan teratur, bencana alam di berbagai tempat, dan semacamnya. Hal tersebut 
merupakan salah satu dampak dari kerusakan lingkungan. Perusahaan dianggap sebagai salah satu penyebab kerusakan lingkungan, karena perusahaanperusahaan cenderung mencari keuntungan yang sebesar-besarnya tanpa memperhatikan dampaknya terhadap lingkungan. Dampak negatif yang ditimbulkan perusahaan terhadap masyarakat cukup besar dan sukar dikendalikan seperti polusi, keracunan, kebisingan, diskriminasi, pemaksaan, kesewenang-wenangan, produksi makanan haram, dan sebagainya. Saat ini perusahaan mulai sadar akan dampak negatif yang ditimbulkan dari operasional perusahaan, hal ini didukung pula dengan regulasi dari pemerintah seperti UndangUndang No. 32 Tahun 2009 tentang Perlindungan dan Pengelolaan Lingkungan Hidup yang mewajibkan bagi setiap perusahaan untuk melakukan pengelolaan lingkungan hidup sehubungan dengan aktivitas usahanya dan memberikan informasi yang benar dan akurat mengenai pengelolaan limbah lingkungan hidup.

Pengelolaan lingkungan menjadi wujud tanggungjawab perusahaan terhadap lingkungan sekitar. Aktivitas yang timbul dari pengelolaan lingkungan maka akan muncul biaya-biaya lingkungan. Perusahaan perlu mengukur biaya lingkungan dari aktivitas pengelolaan lingkungan. Menurut Ikhsan Arfan (2009: 82), biaya lingkungan merupakan dampak, baik moneter maupun nonmoneter sebagai akibat dari kegiatan yang mempengaruhi kualitas lingkungan. Perusahaan memerlukan sistem akuntansi lingkungan sebagai kontrol terhadap tanggung jawab perusahaan sebab pengelolaan limbah yang dilakukan oleh perusahaan memerlukan pengukuran, penilaian, pengungkapan dan pelaporan biaya pengelolaan limbah dari hasil kegiatan operasional perusahaan. Perhitungan biaya dalam penanganan limbah tersebut diperlukan adanya perlakuan akuntansi yang tersistematis secara benar. Akuntansi lingkungan merupakan perkembangan dari akuntansi sosial sebagai bentuk tanggung jawab sosial pada bidang ilmu akuntansi yang berfungsi untuk mengidentifikasi, mengakui, mengukur, menyajikan, dan mengungkapkan akuntansi lingkungan (Islamey, 2016). Perlakuan terhadap masalah penanganan limbah hasil operasional perusahaan ini menjadi sangat penting dalam pengendali pertanggungjawaban perusahaan terhadap lingkungannya. Keuntungan yang dicapai perusahaan dari penerapan akuntansi lingkungan juga bertujuan untuk mengetahui seberapa besar biaya lingkungan yang dikeluarkan dalam mengelolah limbah tersebut dengan menggunakan sistem akuntansi sehingga dapat meminimalkan biaya yang dikeluarkan, dapat mengontrol tanggung jawab perusahaan dalam menjaga lingkungan sekitarnya (Arfan Ikhsan, 2009: 21).

Rumah sakit sebagai organisasi jasa yang bergerak di bidang kesehatan memberikan dampak positif bagi masyarakat dan juga dapat memberikan dampak negatif yaitu limbah yang berpotensi mencemari lingkungan dan menularkan penyakit. Limbah rumah sakit merupakan semua limbah yang dihasilkan dari kegiatan rumah sakit dalam bentuk padat, cair, pasta (gel) maupun gas yang dapat mengandung mikro organisme pathogen bersifat infeksius, bahan kimia beracun, dan sebagian bersifat radioaktif (Depkes, 2006). Badan Rumah Sakit Umum Daerah (BRSUD) Tabanan yang merupakan sebuah perusahaan yang bergerak dalam bidang pelayanan jasa kesehatan masyarakat. Pelayanan jasa Badan Rumah Sakit Umum Daerah (BRSUD) Tabanan berpotensi mengahasilkan limbah. Isu merupakan permasalahan yang berkaitan dengan fenomena atau belum dapat diselesaikan pada tahun sebelumnya dan memiliki dampak jangka panjang bagi keberlanjutan pelaksanaan pembangunan, sehingga perlu diatasi secara bertahap. Isu yang dikutip dari RadarPekalongan.com dikatakan bahwa Badan Rumah Sakit Umum Daerah (BRSUD) Tabanan telah melakukan pengelolaan limbah cair yaitu dengan menggunakan IPAL sistem Biofilter Anaerob-Aerob.

Berdasarkan fenomena yang terjadi Badan Rumah Sakit Umum Daerah (BRSUD) Tabanan melakukan pengelolaan limbah padat menggunakan incinerator dan pengelolaan limbah cair dengan Instalasi Pengelolaan Air Limbah (IPAL). Badan Rumah Sakit Umum Daerah (BRSUD) Tabanan mengeluarkan biaya-biaya terkait pengelolaan limbah. Berdasarkan latar belakang, maka dilakukan penelitian tentang penerapan akuntansi biaya lingkungan dan bagaimana sistem pencatatan pengelolaan limbah yang dihasilkan oleh Badan Rumah Sakit Umum Daerah (BRSUD) Tabanan. Berdasarkan latar belakang yang telah diuraikan, dalam penelitian ini ada beberapa rumusan masalah yaitu sebagai berikut:

1. Apa saja aktivitas-aktivitas lingkungan yang dilakukan Badan Rumah Sakit Umum Daerah (BRSUD) Tabanan dalam upaya untuk mengurangi dampak lingkungan yang di timbulkan akibat kegiatan operasional di Badan Rumah Sakit Umum Daerah (BRSUD) Tabanan?

2. Apakah pelaporan akuntansi lingkungan pada Badan Rumah Sakit Umum Daerah (BRSUD) Tabanan sesuai dengan teori?

3. Apakah Badan Rumah Sakit Umum Daerah (BRSUD) telah mengelola biaya lingkungan sesuai dengan perencanaan anggaran?

\section{B. Tujuan dan Kegunaan Penelitian}

Adapun tujuan dalam penelitian ini dijabarkan sebagai berikut :

1. Menganalisis aktivitas-aktivitas lingkungan yang dilakukan Badan Rumah Sakit Umum Daerah (BRSUD) Tabanan dalam upaya untuk 
mengurangi dampak lingkungan yang di timbulkan akibat kegiatan oprasional di Badan Rumah Sakit Umum Daerah (BRSUD) Tabanan.

2. Mengetahui kesesuain pelaporan akuntansi lingkungan yang dilakukan oleh Badan Rumah Sakit Umum (BRSUD) Tabanan dengan teori.

3. Mengetahui pengelolaan biaya lingkungan Badan Rumah Sakit Umum Daerah (BRSUD) Tabanan sesuai dengan perencanaan anggaran.

\section{TINJAUAN PUSTAKA DAN KERANGKA PENELITIAN}

\section{A. Tinjauan Pustaka}

\section{Lingkungan}

Lingkungan Menurut ISO 14001 adalah keadaan sekeliling dimana organisasi beroperasi, termasuk udara, air, tanah, sumber daya alam, flora, fauna, manusia dan interaksinya. Lingkungan di Indonesia sering disebut lingkungan hidup. Menurut Undangundang no 23 tahun 1997 tentang Pengelolaan Lingkungan Hidup, definisi lingkungan hidup adalah kesatuan ruang dengan semua benda, daya, keadaan, dan makhluk hidup, termasuk manusia dan prilakunya, yang mempengaruhi kelangsungan peri kehidupan dan kesejahteraan manusia serta makhluk hidup lain. Dampak lingkungan adalah perubahan apa pun yang terjadi pada lingkungan, baik yang merugikan maupun yang bermanfaat, yang keseluruhannya atau sebagian disebabkan oleh lingkungan dan organisasi.

\section{Pengertian Akuntansi Lingkungan}

Akuntansi lingkungan (Enviromental Accounting atau EA) merupakan istilah berkaitan dengan dimasukkannya biaya lingkungan (enviromental cost) ke dalam praktik akuntansi perusahaan atau lembaga pemerintahan. Akuntansi lingkungan didefinisikan sebagai pencegahan, pengurangan dan atau penghindaran dampak terhadap lingkungan, bergerak dari kesempatan, dimulai dari perbaikan kembali kejaidan-kejadian yang menimbulkan bencana atas kegiatan-kegiatan tersebut. (Arfan Ikhsan, 2008:14). Akuntansi lingkungan pada dasarnya menuntut kesadaran penuh perusahaanperusahaan maupun organisasi lainnya yang telah mengambil manfaat dari lingkungan. Akuntansi adalah istilah yang luas yang digunakan dalam jumlah konteks yang berbeda (Arfan Ikhsan, 2009:16), seperti:

a) Penilaian dan pengungkapan lingkungan terkait informasi keuangan dalam konteks akuntansi keuangan dan pelaporan

b) Penilaian dan penggunaan lingkungan terkait informasi fisik dan keuangan dalam konteks Akuntansi Manajemen Lingkungan

c) Estimasi atas dampak eksternal lingkungan dan biaya-biaya, sering mengacu pada Full Cost Accounting (FCA).

Akuntansi lingkungan dapat selanjutnya digambarkan dalam dua area utama, yaitu (Arfan Ikhasan, 2009:84) :

a) Akuntansi lingkungan keuangan

b) Akuntansi manajerial

\section{Tujuan Penerapan Akuntansi Lingkungan}

Tujuan akuntansi lingkungan adalah untuk meningkatkan jumlah informasi relevan yang dibuat bagi mereka yang memerlukan atau dapat menggunakannya. Tujuan lain dari pengungkapan akuntansi lingkungan berkaitan dengan kegiatan konservasi lingkungan oleh perusahaan maupun organisasi lainnya yaitu mencakup kepentingan organisasi publik dan perusahan-perusahaan publik yang bersifat lokal. Menurut Arfan Ikhsan (2009:21) tujuan dan maksud dikembangkannya akuntansi lingkungan yaitu sebagai berikut :

a) Akuntansi lingkungan merupakan alat manajemen lingkungan, sebagai alat manajemen lingkungan. Akuntansi lingkungan digunakan untuk menilai keefektifan kegiatan konservasi lingkungan. Data akuntansi lingkungan juga digunakan untuk menentukan biaya fasilitas pengelolaan lingkungan, biaya keseluruhan konservasi lingkungan dan juga investasi yang diperlukan untuk kegiatan pengelolaan lingkungan.

b) Akuntansi lingkungan sebagai alat komunikasi dengan masyarakat, sebagai alat komunikasi publik, akuntansi lingkungan digunakan untuk menyampaikan dampak negatif lingkungan, kegiatan konservasi lingkungan dan hasilnya kepada publik. Tanggapan dan pandangan masyarakat digunakan sebagai umpan balik untuk mengubah pendekatan perusahaan dalam pelestarian atau pengelolaan lingkungan.

\section{Pentingnya Akuntansi Lingkungan.}

Akuntansi lingkungan menjadi hal yang penting untuk dapat dipertimbangkan dengan sebaik mungkin karena akuntansi lingkungan merupakan bagian akuntansi atau sub akuntansi. Alasan yang mendasari adalah mengarah pada keterlibatannya dalam konsep ekonomi dan informasi lingkungan. Akuntansi lingkungan juga merupakan suatu bidang yang terus berkembang dalam mengidentifikasi pengukuran-pengukuran dan mengkomunikasikan biaya-biaya aktual perusahaan atau dampak potensial lingkungannya (Arfan Ikhsan, 2009: 26).

\section{Fungsi dan Peranan Akuntansi Lingkungan}

Pentingnya penggunaan akuntansi lingkungan 
bagi perusahaan atau organisasi lainnya dijelaskan dalam fungsi dan peran akuntansi lingkungan. Fungsi dan peran tersebut dibagi kedalam dua bentuk. Fungsi pertama disebut dengan fungsi internal dan fungsi kedua disebut fungsi eksternal (Arfan Ikhsan, 2009:32). Masing-masing fungsi tersebut dijelaskan sebagai berikut:

\section{a) Fungsi Internal}

Fungsi internal merupakan fungsi yang berkaitan dengan pihak internal perusahaan sendiri. Pihak internal adalah pihak yang menyelenggarakan usaha, seperti rumah tangga konsumen dan rumah tangga produksi maupun jasa lainnya. Adapun yang menjadi aktor dan faktor dominan pada fungsi internal ini adalah pimpinan perusahaan. Sebab pimpinan perusahaan merupakan orang yang bertanggungjawab dalam setiap pengambilan keputusan maupun penentuan setiap kebijakan internal perusahaan.

b) Fungsi Eksternal

Fungsi eksternal merupakan fungsi yang berkaitan dengan aspek pelaporan keuangan. Fungsi ini faktor penting yang perlu diperhatikan perusahaan adalah pengungkapan hasil dari kegiatan konservasi lingkungan dalam bentuk data akuntansi. Informasi yang diungkapkan merupakan hasil yang diukur secara kuantitatif dari kegiatan konservasi lingkungan. Termasuk didalamnya adalah informasi tentang sumbersumber ekonomi suatu perusahaan. Fungsi eksternal memberikan kewenangan bagi perusahaan untuk mempengaruhi pengambilan keputusan stakeholder, seperti pelanggan, rekan bisnis, investor, penduduk lokal maupun bagian administrasi.

\section{Akuntansi Manajemen Lingkungan}

Akuntansi manajemen lingkungan merupakan sub bab bagian dari akuntansi lingkungan. Umumnya digunakan untuk menyediakan informasi dalam pengambilan keputusan suatu organisasi, walaupun informasi dihasilkan untuk tujuan yang lain, seperti pelaporan eksternal. Padangan bahwa akuntansi manajemen lingkungan secara dominan berhubungan terhadap penyediaan informasi untuk pengambilan keputusan internal yang konsisten (EPA 1995). Menurut EPA mendefinisikan akuntansi manajemen lingkunngan sebagai proses pengidentifikasian, pengumpulan dan penganalisisam informasi tentang biaya-biaya dan kinerja untuk membantu pengambilan keputusan organisasi (Arfan Ikhsan, 2009:49). Akuntansi manajemen lingkungan pada dasarnya lebih menekankan pada akuntansi dari biaya-biaya. Biaya lingkungan ini tidak hanya mengenai informasi tentang biaya-biaya lingkungan dan informasi lainnya yang terukur, akan tetapi juga tentang informasi material dan energi yang digunakan.
Akuntansi manajemen lingkungan saling terkait dan terfokus pada arus nilai-nilai dan bahan dan energi, tingkat umum perusahaan yang sama baiknya dengan tingkat proses perusahaan perseroan, divisidivisi, operasi dan lain-lain (Arfan Ikhsan, 2009:50).

\section{Biaya Lingkungan}

Biaya lingkungan adalah dampak, baik moneter atau non-moneter yang terjadi oleh hasil aktifitas perusahaan yang berpengaruh pada kualitas lingkungan (Arfan Ikhsan, 2009:82). Definisi biaya lingkungan mencakup seluruh biaya-biaya paling nyata (seperti limbah buangan), untuk mengukur ketidakpastian (Arfan Ikhsan, 2009:103). Biaya lingkungan pada dasarnya berhubungan dengan biaya produksi, proses, sistem atau fasilitas penting untuk pengambilan keputusan manajemen yang lebih baik. Biaya lingkungan meliputi biaya internal dan eksternal dan berhubungan dengan seluruh biaya yang terjadi dalam hubungannya dengan kerusakan lingkungan dan perlindungan (Arfan Ikhsan, 2009:104). Sebelum informasi biaya lingkungan dapat diberikan kepada manajemen, biaya lingkungan harus didefinisikan. Biaya lingkungan dapat disebut sebagai biaya kualitas lingkungan. Sama halnya dengan biaya kualitas, biaya lingkungan adalah biaya-biaya yang terjadi karena adanya kualitas lingkungan yang buruk atau karena kualitas lingkungan yang buruk mungkin terjadi. Biaya lingkungan menurut Hansen dan Mowen (2009: 403):

a) Biaya pencegahan (enviromental prevention costs) adalah biaya-biaya untuk aktivitas yang dilakukan untuk mencegah diproduksinya limbah dan/atau sampah yang dapat merusak lingkungan. Contoh aktivitas-aktivitas pencegahan adalah evaluasi dan pemilihan pemasok, evaluasi dan pemilihan alat untuk mengendalikan polusi, desain proses dan produk untuk mengurangi atau menghapus limbah, melatih pegawai, mempelajari dampak lingkungan, audit resiko lingkungan, pelaksanaan penelitian lingkungan, pengembangan sistem manajemen lingkungan, daur ulang produk, serta pemerolehan sertifikat ISO 14001

b) Biaya deteksi lingkungan (enviromental detection costs) adalah biaya-biaya untuk aktivitas lain di perusahaan telah memenuhi standar lingkungan yang berlaku atau tidak. Contoh aktivitas deteksi lingkungan adalah audit aktivitas lingkungan, pemeriksaan produk dan proses (agar ramah lingkungan), pengembangan ukuran kinerja lingkungan, pelaksanaan pengujian pencemaran, verifikasi kinerja lingkungan dari pemasok, serta pengukuran tingkat pencemaran.

c) Biaya kegagalan internal (enviromental internal 
failure cost) adalah biaya-biaya untuk aktivitas yang dilakukan karena diproduksinya limbah dan sampah, tetapi tidak dibuang ke lingkungan luar. Contoh aktivitas kegagalan internal adalah pengoperasioan peralatan untuk mengurangi atau menghilagkan polusi, pengolahan dan pembuangan limbah beracun, pemeliharaan peralatan polusi, lisensi fasilitas untuk memproduksi limbah, serta daur ulang sisa bahan.

d) Biaya kegagalan eksternal lingkungan (enviromental external failure costs) adalah biaya-biaya untuk aktivitas yang dilakukan setelah melepas limbah atau sampah kedalam lingkungan. Contoh aktivitas kegagalan eksternal adalah membersihkan tanah yang tercemar, menyelesaikan klain kecelakaan pribadi (yang berhubungan dengan lingkungan), merestorasi tanah ke keadaan alamiah, hilangnya penjualan karena reputasi lingkungan yang buruk, menggunakan bahan baku dan listrik secara tidak efisien, menerima perawatan medis karena polusi, hilangnya lapangan pekerjaan karena pencemaran, hilangnya manfaat danau sebagai tempat rekreasi, dan rusaknya ekosistem karena pembuangan sampah padat.

\section{Tahap-Tahap Perlakuan Alokasi Biaya Lingkungan}

Sebelum mengalokasikan pembiayaan untuk pengelolaan dampak lingkungan seperti pengelolaan limbah, pencemaran lingkungan, pencemaran udara, pencemaran suara dan efek sosial lainnya, perusahaan perlu merencanakan tahap pencatatan pembiayaan tersebut. Tahap-tahap ini dilakukan agar dalam pengalokasian anggaran yang telah direncanakan untuk satu periode akuntansi dapat diterapkan dengan efektif dan efisien (Mulyani, 2013). Pencatatan untuk mengelola segala macam yang berkaitan dengan limbah sebuah perusahaan didahului dengan perencanaan yang akan dikelompokkan dalam pos-pos tertentu sehingga dapat diketahui kebutuhan riil setiap tahunnya. Pengelompokkan dalam tahap analisis lingkungan sebagaimana yang ditentukan dalam Pernyataan Standar Akuntansi Keuangan (PSAK) tahun 2009 antara lain sebagai berikut:

a) Identifikasi

Pertama kali perusahaan akan menentukan biaya untuk pengelolaan biaya penanggulangan eksternality yang mungkin terjadi dalam kegiatan operasional usahanya adalah dengan mengidentifikasi dampak negatif tersebut. Misalkan sebuah Rumah Sakit yang diperkirakan akan menghasilkan limbah berbahaya sehingga memerlukan penanganan khusus untuk hal tersebut mengidentifikasi limbah yang mungkin ditimbulkan antara lain : limbah padat, cair, maupun radioaktif yang berasal dari kegiatan instalasi rumah sakit atau kegiatan karyawan maupun pasien (Hadi, 2012).

b) Pengakuan

Apabila sudah diidentifikasi selanjutnya diakui sebagai akun atau rekening biaya pada saat penerimaan manfaat dari sejumlah nilai yang telah dikeluarkan untuk pembiayaan lingkungan. Biaya yang digunakan oleh perusahaan setiap bulannya untuk mengelola limbah perusahaan dengan cara mengambil dari biaya yang sudah dicadangkan (dianggarkan) sebelumnya yakni melalui pembiayaan dibaya dimuka. (Cahya Ningsih, 2016).

c) Pengukuran

Pengukuran (measurement) adalah penentuan angka atau satuan pengukur terhadap suatu objek untuk menunjukkan makna tertentu dari objek tersebut (Suwardjono dalam Mulyani, 2013). Pada umumnya, perusahaan mengukur biayabiaya yang dikeluarkan oleh perusahaan untuk pengelolaan lingkungan dengan menggunakan satuan moneter yang sudah ditetapkan sebelumnya dan sebesar yang dikeluarkan. Diperoleh jumlah dan nilai yang tepat sesuai kebutuhan riil perusahaan setiap periode.

d) Pengungkapan

Pengungkapan (disclosure) berkaitan cara pembebanan atau penjelasan hal-hal informatif yang dianggap penting dan bermanfaat bagi pemakai laporan keuangan. Menurut standar akuntansi yang berisi tentang informasi atau objek harus disajikan secara terpisah dan statemen utama, apakah suatu pos perlu dirinci atau apakah suatu informasi cukup disajikan dalam bentuk catatan kaki (foot note) (Suwardjono, 2013).

\section{Corporate Socila Responsibility (CSR)}

Corporate Social Responsibility (CSR) didefinisikan sebagai tanggung jawab sosial suatu perusahaan kepada para stakeholders, terutama komunitas atau masyarakat di sekitar wilayah kerja operasinya (Hamdani, 2016: 170). Penerapan CSR di perusahaan, khususnya rumah sakit akan menciptakan suatu hubungan harmonis antara perusahaan dan masyarakat. Salah satu tanggung jawab sosial perusahaan yang dikemukakan oleh Elkington di atas adalah dengan menjaga kelestarian alam ataupun lingkungan. Apabila rumah sakit menerapkan akuntansi lingkungan dalam kegiatan operasinya, artinya juga secara tidak langsung rumah sakit telah menjalankan Corporate Social Responsibility (CSR) dengan baik. Kedisiplinan tersebut dapat dilihat dari pengungkapan segala kegiatan yang berhubungan dengan pengelolaan 
lingkungan melalui akuntansi lingkungan.

\section{Limbah Rumah Sakit}

Pengertian limbah rumah sakit adalah semua limbah yang dihasilkan dari kegiatan Rumah Sakit dalam bentuk padat, cair, pasta (gel) maupun gas yang dapat mengandung mikroorganisme pathogen bersifat infeksius, bahan kimia beracun, dan sebagian bersifat radioaktif (Depkes, 2006). Limbah rumah sakit cenderung bersifat infeksius dan kimia beracun yang dapat mempengaruhi kesehatan manusia, memperburuk kelestarian lingkungan hidup apabila tidak dikelola dengan baik. Limbah rumah sakit ada dua jenis yaitu:

a) Limbah Padat

Limbah padat rumah sakit adalah semua limbah rumah sakit yang berbentuk padat akibat kegiatan rumah sakit yang terdiri dari limbah medis padat dan non medis (Keputusan MenKes R.I. No.1204/MENKES/SK/X/2004), yaitu:

1) Limbah non medis adalah limbah padat yang dihasilkan dari kegiatan di luar medis yang berasal dari dapur, perkantoran, taman dan halaman yang dapat dimanfaatkan kembali apabila ada teknologi. Penyimpanannya pada tempat sampah berplastik hitam

2) Limbah medis padat adalah limbah padat yang terdiri dari :

Limbah padat medis dapat dikelola dengan menggunakan Incinerator. Incinerator adalah suatu alat pembakar sampah yang dioprasikan dengan menggunakan teknologi pembakaran suhu tertentu, sehingga sampah dapat terbakar habis sampai menjadi debu. Incinerator merupakan sebuah alat khusus menyerupai tungku yang digunakan untuk membakar limbah padat dengan suhu tinggi. Limbahlimbah padat tersebut kemudian dimasukkan ke dalam Incinerator dan dibakar selama dua jam dengan suhu 1.200o Celcius dan menghabiskan 30 liter minyak tanah tiap kali pembakaran.

b) Limbah Cair

Limbah cair rumah sakit adalah semua air buangan termasuk tinja yang berasal dari kegiatan rumah sakit, yang kemungkinan mengandung mikroorganisme bahan beracun, dan radio aktif serta darah yang berbahaya bagi kesehatan (Depkes RI, 2006). Penanganannya melalui IPAL (Instalasi Pengolahan Air Limbah).

Insatalasi Pengolahan Air Limbah (IPAL) adalah bangunan air yang berfungsi untuk mengolah air buangan yang berasal dari kegiatan yang ada di fasilitasi pelayanan kesehatan. Salah satu sistem IPAL yang telah banyak digunakan pada beberapa fasilitas pelayanan kesehatan adalah IPAL dengan sistem biofilter anaerob aerob.
1) Proses Biofilter
2) Proses Biofilter Aerob
3) Proses Biofilter Anaerob Aerob

\section{B. Kerangka Pemikiran Penelitian}

Berkaitan dengan penelitian ini dapat dibuatkan kerangka pemikiran sebagai berikut:

Gambar 1

Kerangka Pemikiran Penelitian Analisis Penerapan Akuntansi Lingkungan Pada Badan Rumah Sakit Umum Daerah (BRSUD) Tabanan

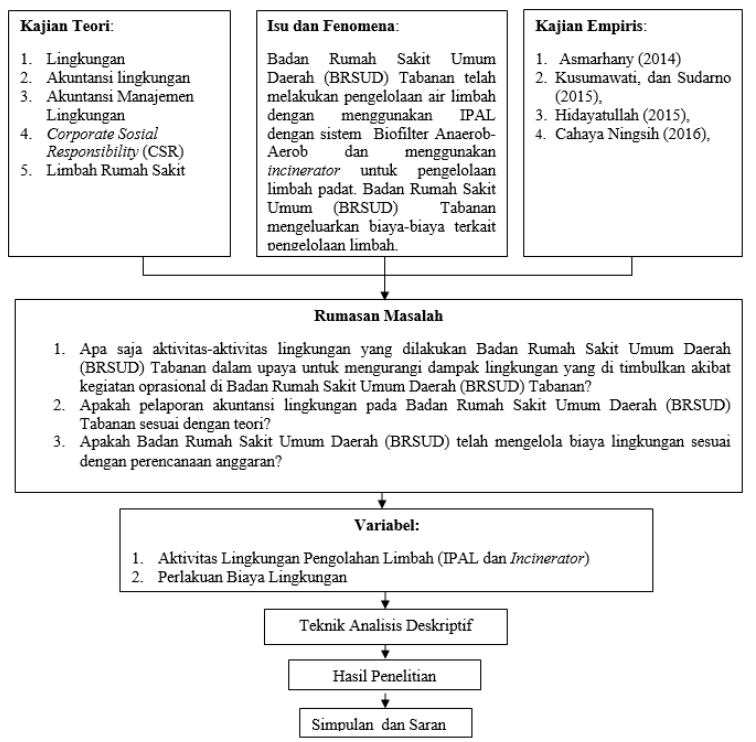

Sumber : Data diolah, (2017) 


\section{METODE PENELITIAN}

\section{A. Tempat Penelitian}

Penelitian ini dilakukan pada Badan Rumah Sakit Umum Daerah (BRSUD) Tabanan yang beralamat di Jl. Pahlawan No. 14 Tabanan - 82114, Bali. Telepon (0361) 811027.

Obyek penelitian adalah aktivitas yang dilakukan dalam pengelolaan limbah (IPAL dan Incinerator) dan perlakuan biaya lingkungan yang dikeluarkan dalam kegiatan pengelolaan limbah pada Badan Rumah Sakit Umum Daerah (BRSUD) Tabanan.

\section{B. Identifikasi Variabel}

Variabel penelitian adalah suatu atribut atau sifat atau nilai dari orang, obyek atau kegiatan yang mempunyai variasi tertentu yang ditetapkan oleh peneliti untuk dipelajari dan kemudian ditarik kesimpulannya (Sugiyono, 2014: 61). Variabel penelitian yang digunakan dalam penelitian ini adalah aktivitas yang dilakukan oleh Badan Rumah Sakit Umum Daerah (BRSUD) Tabanan, dan perlakuan biaya lingkungan yang muncul dari aktivitas pengolahan limbah Badan Rumah Sakit Umum Daerah (BRSUD) Tabanan.

\section{Definisi Oprasional Variabel}

Variabel-variabel yang digunakan dalam penelitian ini adalah:

\section{Aktivitas Lingkungan}

Aktivitas lingkungan merupakan aktivitasaktivitas yang dilakukan Badan Rumah Sakit Umum Daerah (BRSUD) Tabanan sebagai pertanggungjawaban rumah sakit yang berhubungan dengan pencemaran lingkungan yang timbul akibat proses kegiatan oprasional rumah sakit. Aktivitas lingkungan ini yaitu aktivitas yang dapat dilakukan untuk mencegah pencemaran lingkungan, yaitu aktivitas pencegahan, meliputi aktivitas pelatihan lingkungan untuk karyawan serta sekolah lapangan konservasi, aktivitas penilaian, yang meliputi kualitas pengujian kualitas udara dan pengujian kualitas air, aktivitas kegagalan internal, yang meliputi pembuangan sampah, aktivitas kegagalan ekternal, yang meliputi membersihkan waduk dan penghijuan. Indikator aktivitas lingkungan yaitu pengelolaan limbah cair dan padat.

\section{Biaya Lingkungan}

Biaya lingkungan adalah biaya yang ditimbulkan akibat adanya kualitas lingkungan yang rendah, sebagai akibat dari proses produksi yang dilakukan Badan Rumah Sakit Umum Daerah (BRSUD) Tabanan. Biaya lingkungan perlu dilaporkan terpisah berdasarkan klasifikasi biayanya agar laporan biaya lingkungan dapat dijadikan informasi yang informatif untuk mengevaluasi kinerja oprasioal perusahaan terutama yang berdampak pada lingkungan. Indikator dari biaya lingkungan adalah biaya pencegahan, biaya penilaian, biaya kesalahan internal, biaya kesalahan eksternal, dan nilai tambah.

\section{Jenis Data}

Data yang digunakan adalah data kualitatif adalah data yang tidak dinyatakan dalam bentuk angka yaitu berupa penjelasan-penjelasan dan tidak dapat diukur dengan satuan hitung seperti informasi mengenai pengolahan limbah, dan perlakuan biaya lingkungan pada Badan Rumah Sakit Umum Daerah (BRSUD) Tabanan.

\section{E. Sumber data}

Data yang digunakan dalam penelitian ini bersumber dari data sekunder. Data sekunder adalah data yang diperoleh dari sumber penelitian dengan mempelajari refrensi yang memiliki hubungan dengan sasaran penelitian. Data sekunder yang digunakan pada penelitian ini diperoleh dengan mengumpulkan catatan-catatan akuntansi dari Badan Rumah Sakit Umum Daerah (BRSUD) Tabanan dan laporan mengenai program penyehatan lingkungan yang dijalankan.

\section{F. Metode Pengumpulan Data}

Metode pengumpulan data ini dilakukan di Badan Rumah Sakit Umum Daerah (BRSUD) Tabanan. Pengumpulan data dari sumber data ini dilakukan dengan cara:

\section{Observasi}

Observasi digunakan bila penelitian berkenaan dengan perilaku manusia, proses kerja, gejala-gejala alam dan bila responden yang diamati tidak terlalu besar (Sugiyono, 2014: 203). Peneliti melakukan pengamatan secara langsung terhadap segala aktivitas yang berkaitan dengan penerapan akuntansi lingkungan pada Badan Rumah Sakit Umum Daerah (BRSUD) Tabanan.

\section{Wawancara (interview)}

Wawancara dilakukan dengan tanya jawab langsung kepada pihak Badan Rumah Sakit Umum Daerah (BRSUD) Tabanan terkait yaitu bagian keuangan dan akuntansi dalam melakukan penelusuran biaya-biaya lingkungan yang terjadi selama periode tertentu serta dalam mencari informasi mengenai perlakuan akuntansi terhadap biaya-biaya lingkungan. Wawancara juga dilakukan pada bagian sanitasi dan kesehatan lingkungan Badan Rumah Sakit Umum Daerah (BRSUD) Tabanan untuk mendapatkan informasi mengenai pengelolaan limbah yang dihasilkan Badan Rumah Sakit Umum Daerah (BRSUD) Tabanan.

\section{Dokumentasi}

Metode pengumpulan data dengan dokumentasi 
adalah mengumpulkan catatan-catatan akuntansi dari Badan Rumah Sakit Umum Daerah (BRSUD) Tabanan serta dokumen lainnya yang relevan dengan penelitian ini berupa dan pedoman kebijakan perusahaan untuk pengolahan limbahnya dan catatan -catatan terkait biaya lingkungan Badan Rumah Sakit Umum Daerah (BRSUD) Tabanan.

\section{G. Teknik Analisis Data}

Teknik analisis data yang digunakan dalam penelitian ini yaitu teknik analisis deskriptif. Analisis deskriptif adalah analisis yang digunakan untuk menganalisa data dengan cara mendeskripsikan atau menggambarkan data yang telah terkumpul sebagaimana adanya tanpa bermaksud membuat kesimpulan yang berlaku umum atau generalisasi (Sugiono, 201:206). Penelitian ini dilakukan dengan medeskripsikan hasil temuannya yang semua berasal dari data yang terkumpul melalui proses observasi laporan keuangan yang dibuat Badan Rumah Sakit Umum Daerah (BRSUD) Tabanan, mengenai jenis-jenis limbah dan tata cara pengelolannya, mengenai perhitungan, penilaian biaya, dan alokasi pengelolaan limbah pada laporan keuangan Badan Rumah Sakit Umum Daerah (BRSUD) Tabanan, serta mengenai Instalasi Pengolah Air Limbah dan Analisis Mengenai Dampak Lingkungan (AMDAL).

\section{HASIL DAN PEMBAHASAN}

\section{A. Aktivitas Lingkungan pada Badan Rumah Sakit Umum Daerah (BRSUD) Tabanan}

Badan Rumah Sakit Umum Daerah (BRSU) Tabanan sebagai lembaga pelayanan kesehatan masyarakat yang melakukan berbagai macam aktivitas yang berhubungan dengan lingkungan. Aktivitas pengelolaan limbah yang dilakukan oleh Badan Rumah Sakit Umum Daerah (BRSUD) Tabanan seperti yang dijelaskan sebelumnya. Limbah yang dihasilkan yaitu limbah padat (medis dan non medis) dan limbah cair. Limbah yang dihasilkan Badan Rumah Sakit Umum Daerah (BRSUD) Tabanan sebelum diolah dilakukan pemisahan sesuai dengan jenis limbah. Pengolahan limbah dilakukan dengan beberapa metode sesuai jenis limbahnya.

Metode pengelolaan limbah Badan Rumah Sakit Umum Daerah (BRSUD) Tabanan yaitu:

\section{Metode Pengelolaan Limbah Padat Medis}

Pengelolaan limbah padat medis Badan Rumah Sakit Umum Daerah (BRSUD) Tabanan dilakukan dalam 3 langkah pengelolaan. Adapun langkahlangkah pengelolaan limbah padat medis sebagai berikut:

a) Pengumpulan

Semua jenis limbah medis dibuang pada tempat sampah berupa ember plastik berwarna merah tertutup yang telah dialasai dengan kantong plastik warna kuning, khusus limbah medis traumatic (jarum, ampul, benda-benda tajam) terlebih dahulu dimasukkan kedalam jerigen, setelah jerigen terisi $2 / 3$ dapat ditutup kemudain dimasukkan kedalam tempat sampah medis yang telah tersedia di masing-masing ruangan. Kegiatan pengumpulan limbah medis dilaksanakan setiap hari oleh patugas masingmasing ruangan penghasil limbah medis.

b) Pengangkutan

Jika ada ruangan yang menghasilkan sampah gangrein (jaringan tubuh mati) lewat dari jam 10.00 segera dilakukan pengambilan oleh patugas khusus limbah medis dibawa ke tempat penampungan sementara limbah B3. Pengangkutan dilakukan dengan menggunakan kereta sampah kemudian dilakukan penimbangan.

c) Pemusnahan

Pemusnahan limbah medis dengan menggunakan incinerator pada suhu $100^{\circ} \mathrm{C}$ dan menghabiskan 27 liter solar tiap kali pembakaran. Limbah medis yang terkumpul dimasukkan ke dalam incinerator dan dibakar setiap hari dari pukul 10.00 sampai selesai. Pembakaran limbah tersebut dilakukan 2 kali dalam sehari sebanyak 200 kilogram limbah padat. Setelah pembakaran selesai, abu yang dihasilkan dipindahkan ke dalam wadah, kemudian diangkut dibawa ke bak sanitary landfill.

2. Metode Penanganan Limbah Padat Non Medis

Penanganan limbah padat non medis Badan Rumah Sakit Umum Daerah (BRSUD) Tabanan ada 2 langkah yang dilakukan adalah sebagai berikut:

a) Pengumpulan

Sampah yang dihasilkan setiap ruangan yang telah dikumpulkan pada tempat sampah yang dialasi dengan kantong plastik berwarna hitam. Sampah yang telah dikumpulkan akan dibuang sementara di TPS.

b) Pengangkutan ke TPA

Pengangkutan ke TPA dilakuakn oleh DKP Kota Tabanan yang akan dibuang ke TPA di Desa Sembung Gede Kecamatan Kerambitan dengan frekuensi 2 x 1 hari.

\section{Metode Penanganan Limbah Cair}

Limbah cair yang dihasilkan tiap unit pelayanan disalurkan melalui saluran IPAL yang tertutup termasuk resapan dari septic tank, terpisah dengan jalur pembuangan air hujan. Pengumpulan limbah B3 harus menggunakan container yang kuat dan tidak mudah dibuka dan diberi label. Limbah yang berasal dari laboratorium didekontaminasi terlebih 
dahulu dan air sisa pembuangannya disalurkan ke saluran IPAL. Limbah cair yang berasal dari daput (instalasi gizi) sebelum dibuang ke saluran IPAL dipasang bak penangkap lemak. Pihak rumah sakit melakukan pemeriksaan kualitas air hasil pengolahan secara bertahap 1 bulan sekali. Air hasil pengolahan IPAL juga ditampung di dalam kolam ikan. Apabila ikan-ikan dalam kolam tetap hidup, maka dapat dipastikan air hasil olahan IPAL tersebut tidak mengandung zat berbahaya sehingga dapat digunakan lagi untuk keperluan lain seperti menyiram tanaman di lingkungan rumah sakit.

\section{B. Perlakuan Biaya Lingkungan pada Badan Rumah Sakit Umum Daerah (BRSUD) Tabanan}

Akuntansi lingkungan sebagai metode untuk mengungkap dan menyajikan perlakuan biaya yang berhubungan dengan pengelolaan lingkungan memerlukan tahap-tahap yang berurutan dan rinci dengan tetap mengacu pada standar akuntansi maupun pernyataan akuntansi yang berlaku umum. Tahap-tahap akuntansi ini meliputi identifikasi, pengakuan, pengukuran, penyajian, dan pengungkapan. Berikut ini merupakan tahap perlakuan akuntansi lingkungan Badan Rumah Sakit Umum Daerah (BRSUD) Tabanan yang diperbandingkan dengan teori dan prinsip yang berlaku umum:

\section{Pengidentifikasian}

Badan Rumah Sakit Umum Daerah (BRSUD) Tabanan mengidentifikasi biaya-biaya sehubungan dengan pengelolaan limbah sebagai bagian beban layanan, beban administrasi dan umum pada laporan aktivitas. Penelusuran biaya lingkungan yang terjadi dalam Badan Rumah Sakit Umum Daerah (BRSUD) Tabanan dilakukan dengan mengamati anggaran biaya Badan Rumah Sakit Umum Daerah (BRSUD) Tabanan tahun 2016, rincian belanja Badan Rumah Sakit Umum Daerah (BRSUD) Tabanan tahun 2016 serta dengan melakukan wawancara dengan Kepala Urusan Keuangan dan Akuntansi Badan Rumah Sakit Umum Daerah (BRSUD) Tabanan. Setelah memperoleh informasi mengenai biaya lingkungan dan dilakukan perbandingan dengan teori pembagian biaya lingkungan menurut Hansen dan Mowen, maka biaya lingkungan yang terjadi pada Badan Rumah Sakit Umum Daerah (BRSUD) Tabanan tahun 2016 dapat diklasifikasikan sebagai berikut:

a) Biaya pencegahan lingkungan, pada tahun 2016 Badan Rumah Sakit Umum Daerah (BRSUD) Tabanan tidak mengeluarkan biaya pencegahan lingkungan. Namun pada tahun 2009 Badan Rumah Sakit Umum Daerah (BRSUD) Tabanan mengeluarkan biaya pencegahan yaitu biaya untuk melakukan pengelolaan dan pemantauan lingkungan hidup yaitu membuat Dokumen Pengelolaan dan Pemantauan
Lingkungan (DPPL). Ini merupakan semacam studi mengenai dampak lingkungan yang terjadi apabila membangun rumah sakit harus mempunyai ijin Analisis Dampak Lingkungan (AMDAL). Badan Rumah Sakit Umum Daerah (BRSUD) belum memiliki AMDAL, maka rumah sakit diwajibkan membuat Dokumen Pengelolaan dan Pemantauan Lingkungan (DPPL) tersebut. Pada saat itu biaya pencegahan lingkungan yang dikeluarkan Badan Rumah Sakit Umum Daerah (BRSUD) Tabanan sebesar Rp. 13.500.000.

b) Biaya deteksi lingkungan.

Biaya deteksi lingkungan terdiri dari biaya uji emisi untuk pemeriksaan sampel air limbah untuk IPAL dan uji emisi fisik udara dilakukan pada emisi gas buangan yang disebabkan oleh proses pembakaran incinerator yang dilakukan 1 tahun sekali. Jadi biaya deteksi lingkungan yang dikeluarkan Badan Rumah Sakit Umum Daerah (BRSUD) Tabanan untuk uji emisi air limbah sebesar Rp. 4.213.000 atau 0,26\% dari biaya operasional. Sedangkan biaya uji emisi fisik udara terhadap proses pembakaran incinerator sebesar Rp. 11.600 .000 atau $0,71 \%$ dari biaya operasional.

c) Biaya kegagalan internal lingkungan terdiri dari biaya pengelolahan limbah dengan incinerator dan IPAL meliputi biaya yang dikeluarkan untuk pembelian bahan bakar incinerator, biaya gaji petugas incinerator dan IPAL, biaya pemeliharaan incinerator dan IPAL dan biaya penyusutan incinerator dan IPAL. Jumlah keseluruhan biaya kegagalan internal lingkungan yang dikeluarkan Badan Rumah Sakit Umum Daerah (BRSUD) Tabanan sebesar Rp. 444.810 .958 atau sebesar 27,24\% dari biaya operasional.

d) Biaya kegagalan ekternal lingkungan. Badan Rumah Sakit Umum Daerah (BRSUD) Tabanan tidak mengeluarkan biaya kegagalan ekternal karena rumah sakit tidak pernah membuang limbah ke luar lingkungan yang menyebabkan kerugian pada masyarakat lingkungan sekitar.

\section{Pengakuan}

Badan Rumah Sakit Umum Daerah (BRSUD) Tabanan mengakui biaya pada saat sudah memberikan manfaat meskipun kas belum dikeluarkan. Berdasarkan catatan atas laporan keuangan Badan Rumah Sakit Umum Daerah (BRSUD) Tabanan biaya lingkungan dicatat sebagai beban layanan, beban administrasi dan umum dalam laporan aktivitas atau laporan laba rugi Badan Rumah Sakit Umum Daerah (BRSUD) Tabanan dan biaya pemerolehan incinerator dan IPAL dicatat sebagai aset tetap dalam laporan posisi keuangan atau neraca Badan Rumah Sakit Umum Daerah 
(BRSUD) Tabanan.

\section{Pengukuran}

Berdasarkan hasil pengamatan Badan Rumah Sakit Umum Daerah (BRSUD) Tabanan dalam mengukur dan menilai biaya yang dikeluarkan menggunakan satuan moneter rupiah dengan acuan realisasi biaya pada periode sebelumnya dan sebesar kos yang dikeluarkan. Badan Rumah Sakit Umum Daerah (BRSUD) Tabanan memiliki alat pengolahan limbah yaitu IPAL dan incinerator yanng disajikan sebagai aset tetap dalam neraca. Badan Rumah Sakit Umum Daerah (BRSUD) Tabanan dalam menyusutkan aset tetap dengan menggunakan metode garis lurus (straight line method) dengan nilai sisa Rp.0.

\section{Penyajian}

Berdasarkan hasil pengamatan atas penyajian biaya lingkungan, rumah sakit menyajikan biaya lingkungan bersama dengan biaya operasional dalam laporan keuangan Badan Rumah Sakit Umum Daerah (BRSUD) Tabanan. Biaya lingkungan secara umum disajikan dalam beban layanan dan biaya administrasi dan umum dalam laporan aktivitas disajikan sebagai bagian dari aset tetap pada neraca. Tidak ada penyajian secara khusus pada biaya-biaya yang berhubungan dengan pengolahan limbah Badan Rumah Sakit Umum Daerah (BRSUD) Tabanan.

\section{Pengungkapan}

Berdasarkan hasil pengamatan atas pengungkapan biaya lingkungan diungkapkan ke dalam beban layanan dan beban administrasi dan umum pada laporan aktivitas rumah sakit dan diungkap sebagai bagian dari aset tetap dalam laporan posisi keuangan Badan Rumah Sakit Umum Daerah (BRSUD) Tabanan. Pengungkapan biaya lingkungan juga belum memiliki akun khusus atau laporan khusus biaya lingkungan yang terkait dengan pengelolaan limbah rumah sakit. Pengungkapan biaya lingkungan Badan Rumah Umum Daerah (BRSUD) Tabanan dalam laporan keuangan yaitu pada laporan posisi keuangan dan laporan aktivitas adalah seperti berikut:

\section{Pengelolaan Anggaran Biaya Lingkungan Badan Rumah Sakit Umum Daerah (BRSUD) Tabanan}

Badan Rumah Sakit Umum Daerah (BRSUD) Tabanan mengeluarkan anggaran biaya terkait pengelolaan limbah anggaran tersebut dicatat dalam laporan rekapitulasi anggaran rumah sakit tahun 2016. Anggaran yang dimiliki Badan Rumah Sakit Umum Daerah (BRSUD) Tabanan terkait pengelolaan limbah sebesar Rp. 601.155.758, biaya yang telah dikeluarkan terkait pengelolaan limbah sebesar Rp. 460.623.958, terlihat bahwa biaya yang dikeluarkan tidak melibihi jumlah anggaran yang disediakan. Selisih anggaran dengan realisasi yang dimiliki sebesar Rp. 140.531.800, sisa anggaran yang cukup besar dikarenakan perencanaan anggaran terkait pembelian bahan bakar untuk incinerator yang dianggarakan bersamaan dengan pembelian bahan bakar untuk genzet rumah sakit. Pengelolaan anggaran khususnya terkait pengelolaan limbah pada Badan Rumah Sakit Umum Daerah (BRSUD) Tabanan sudah mencapai $76,62, \%$ dari anggaran yang telah disediakan.

\section{PENUTUP}

\section{A. Simpulan}

Berdasarkan hasil observasi dan pembahasan maka dapat disimpulkan sebagai berikut:

1. Aktivitas lingkungan yang dilakukan Badan Rumah Sakit Umum Daerah (BRSUD) Tabanan yaitu aktivitas pengolahan limbah yang dihasilkan dari kegiatan operasional rumah sakit. Limbah yang dihasilkan dari kegiatan operasional rumah sakit berupa limbah padat dan cair. Pengolahan limbah padat yang dilakukan Badan Rumah Sakit Umum Daerah (BRSUD) Tabanan dengan menggunakan incinerator sedangkan untuk pengolahan limbah cair dengan menggunakan Instalasi Pengolahan Air Limbah (IPAL).

2. Badan Rumah Sakit Umum Daerah (BRSUD) Tabanan belum menerapkan perlakuan akuntansi lingkungan karena berdasarkan hasil pengamatan dan penelurusuran yang telah dilakukan tidak terdapat perlakuan khusus terhadap pelaporan biaya-biaya lingkungan dan aktivitas yang dilakukan Badan Rumah Sakit Umum Daerah (BRSUD) Tabanan. Badan Rumah Sakit Umum Daerah BRSUD) Tabanan mengidentifikasi biaya terkait pengelolaan limbah sebagai belanja langsung dan tidak langsung, apabila dibandingkan dengan teori, biaya kualitas lingkungan yang dikeluarkan sebesar 28,21\% dari biaya operasional, mengakui biaya lingkungan pada saat sudah mendapat manfaat dari hal tersebut meskipun kas belum dikeluarkan, pengukuran biaya lingkungan dengan satuan moneter rupiah yang mengacu pada realisasi biaya periode sebelumnya sebesar kos yang dikeluarkan. Biaya lingkungan disajikan dan diungkapkan secara keseluruhan dalam laporan keuangan Badan Rumah Sakit Umum Daerah (BRSUD) Tabanan pada biayabiaya sejenis seperti beban layanan, beban administrasi dan umum dalam laporan laba rugi, dan sebagai bagian dari aset tetap dalam neraca. Badan Rumah Sakit Umum Daerah (BRSUD) Tabanan tidak membuat laporan khusus terkait biaya lingkungan.

3. Badan Rumah Sakit Umum Daerah (BRSUD) Tabanan tidak memiliki anggaran khusus biaya lingkungan, namun anggaran biaya tersebut 
dicatat secara keseluruhan dalam laporan rekapitulasi anggaran biaya. Perencanaan anggaran biaya lingkungan Badan Rumah Sakit Umum Daerah (BRSUD) Tabanan tahun 2016 sudah mencapai $76,62 \%$. Biaya yang dikeluarkan tidak melebihi anggaran yang disediakan, selisih anggaran dengan realiasi sebesar Rp. 140.531.800.

\section{B. Saran}

Berdasarkan simpulan penelitian maka dapat disampaikan saran sebagai berikut:

1. Bagi pihak Badan Rumah Sakit Umum Daerah (BRSUD) Tabanan apabila ingin meningkatkan penerapan akuntansi lingkungan dengan lebih baik lagi, rumah sakit dapat membuat laporan biaya lingkungan sederhana yang bisa mengungkap seluruh biaya yang berkaitan dengan pengolahan limbah dengan lebih terperinci. Laporan biaya lingkungan tersebut akan menjadi suatu motivasi bagi pihak manajemen dalam meningkatkan efektivitas dan efisiensi pengolahan limbah.

2. Diharapkan agar Badan Rumah Sakit Umum Daerah (BRSUD) Tabanan membuat laporan anggaran khusus terkait biaya lingkungan sehingga dapat mengetahui sejauh mana pengelolaan limbah yang telah dilakukan agar sesuai dengan perencanaan yang telah dianggarkan sebelumnya.

3. Kepada manajemen bidang kesehatan lingkungan (kesling) Badan Rumah Sakit Umum Daerah (BRSUD) Tabanan agar memilah limbah-limbah padat non medis yang masih bisa di daur ulang atau dijual kembali agar dapat bermannfaat dan menghasilkan pendapatan bagi Badan Rumah Sakit Umum Daerah (BRSUD) Tabanan.

4. Peneliti selanjutnya diharapkan untuk menambahkan objek penelitian terkait dampak kinerja lingkungan terhadap masyarakat sekitar.

\section{DAFTAR PUSTAKA}

Hamdani. 2016. Good Corporate Governance: Tinjauan Etika dalam Praktik Bisnis. Mitra Wacana Media.

Hansen dan Mowen. 2009. Akuntansi Manajemen. Edisi 8. Jakarta. Salemba Empat.

Ikatan Akuntan Indonesia. 2009. Standar Akuntansi Keuangan. Jakarta: Penerbit Salemba Empat.

Ikhsan, Arfan. 2009. Akuntansi Manajemen Lingkungan. Yogyakarta : Graha Ilmu.

Ikhsan, Arfan. 2008. Akuntansi Lingkungan dan Pengungkapannya. Yogyakarta : Graha Ilmu

Keputusan Menkes R. I. No. 1204/MENKES/SK/
$\mathrm{X} / 2004$ tentang Persyaratan Kesehatan Rumah sakit.

Kemenkes RI Direktorat Jendreal Bina Upaya Kesehatan. 2011. Pedoman Teknis Instalasi Pengolahan Air Limbah.

Mardikanto, Totok. 2014. CSR (Corporate Social Responsibility) (Tanggungjawab Sosial Korporasi). Bandung: Alfabeta

Republik Indonesia. 2009. Undang-Undang No. 32 Tahun 2009 tentang Perlindungan dan Pengelolaan Lingkungan Hidup. Jakarta:Sekretariat Negara.

Sugiyono. 2014. Metode Penelitian Bisnis. Bandung: Alfabeta

Asmarhany, Chandra Dewi. 2014. Pengelolaan Limbah Medis Padat di Rumah Sakit Umum Daerah Kabupaten Jepara. Skripsi : Jurusan Ilmu Kesehatan Masyarakat Jurusan Ilmu Keolahragaan Universitas Negeri Surabaya.

Hidayatullah. Moh. Syarif. 2015. Analisis Penerapan Akuntansi Lingkungan Untuk Mengetahui Poses Pengelolaan Limbah Dan Tanggungjawab Sosial Pada Rumah Sakit Ibnu Sina Kota Gresik. Jurnal.Universitas Islam Negeri.

Hadi, Shofyan. 2012. Analisis Penerapan Akuntansi Lingkungan Pada PT Istana Cipta Sembada Banyuwangi. Skripsi: Fakultas Ekonomi Universitas Jember.

Islamey, Fika Erisya. 2016. Perlakuan Akuntansi Terhadap Pengelolaan Limbah Pada Rumah Sakit Paru Jember. Jurnal. Universitas Muhammadiyah Jember.

Kusumawati, Titik, dan Sudarno, 2015. Perlakuan Akuntansi Atas Pengelolaan Limbah Pada RSUD Dr. R. Koesma Tuban. Skripsi : Fakultas Ekonomi Universitas Jember.

Mulyani, Nita Sri. 2013. Analisis Penerapan Akuntansi Biaya Lingkungan pada Pabrik Gondorukem dan Terpentin (PGT) GarahanJember. Sripsi. Universitas Jember

Nilasari, Fitri. 2014. Analisis Penerapan Akuntansi Lingkungan Terhadap Pengeloaan Limbah. Jurnal. Universitas Jember.

Badan Rumah Sakit Umum Daerah Tabanan "Profil Badan Rumah Sakit Umum Daerah Tabanan". Tersedia pada www.brsu.tabanankab.go.id (diakses pada 15 Juni2017).

RSUP Dr. Hasan Sadikin Bandung. "Limbah Rumah Sakit". Tersedia pada http://web.rshs.or.id/ limbah-rumah-sakit/(diakses pada (12 Maret 2017). 